\title{
Is globalization influencing primary energy consumption? The case of Latin American and Caribbean countries
}

\author{
É a globalização que influencia o consumo de energia primária? o caso \\ dos países da América Latina e Caribe
}

\author{
1 Matheus Koengkan
}

1 Management and Economics Department, NECE-UBI and University of Beira Interior, Covilhã, Portugal, matheuskoen@hotmail. com.br

\begin{abstract}
This article investigates the relationship between globalization and primary energy consumption in twelve Latin American and Caribbean countries from 1991 to 2012 using the auto-regressive distributive lag (ARDL) methodology. The elasticities results showed that increase of $1 \%$ on index globalization exerts a positive impact of $0.4449 \%$ on primary energy consumption. The variables gross domestic product (GDP) and dioxide carbon emissions (CO2) also exert a positive impact in short and long-run as well as the variable capital account openness has a negative effect in long-run.
\end{abstract}

\section{Keywords}

Globalization; Latin America and Caribbean countries; Primary energy consumption; ARDL; GDP; $\mathrm{CO}_{2}$; Capital account openness.

\section{Resumo}

Este artigo investiga a relação entre a globalização e o consumo de energia primária em doze países da América Latina e Caribe no período de 19912012, utilizando como metodologia o modelo autoregressivo com desfasamentos distribuídos (ARDL). Os resultados das elasticidades evidenciaram que aumento de $1 \%$ no índice de globalização exerce um impacto positivo de $0,4449 \%$ sobre o consumo de energia primária. Além disso, as variáveis produto interno bruto (PIB) e emissões de dióxido de carbono $\left(\mathrm{CO}_{2}\right)$ exercem um impacto positivo no curto e longo prazo, bem como a abertura da a abertura de capital tem um efeito negativo no longo prazo.

\section{Palavras-chave}

Globalização; América Latina e Caribe; Consumo de energia primária; $A R D L ; P I B ; C_{2}$; Abertura de capital.

\section{Como você deve citar?}

KOENGKAN, Matheus. Is globalization influencing primary energy consumption? The case of Latin American and Caribbean countries. Cadernos UniFOA, Volta Redonda, n. 33, p. 59-69, abr. 2017. 


\section{INTRODUCTION}

The economic policy considers that globalization is a process correlated with international trade and foreign direct investment (Leitão, 2014). The globalization allows the transfer of advanced technology from rich to poor countries, helping in the promotion of division of labour, and increasing the comparative advantage between different nations, as well as it improves the total productivity factor and promotes the economic growth that influences energy demand (Shahbaz et al.2015). The objective of this article is to analyze the relationship between globalization and primary energy consumption in twelve Latin American and Caribbean (LAC) countries in the period from 1991 to 2012.

In the literature review, the impact of globalization on economic growth has been described by several authors. For instance, Gurgul and Lach (2014) examined the role of various aspects of globalization on economic growth in ten CEE economies in the period 1990-2009. The authors found a strong and robust evidence of growth-stimulating effect of globalization processes, especially in social and economic dimensions. Ying et al. (2014) analyzed the influence of short-run dynamics and long-run equilibrium relationships between globalization and the growth of 12 countries of the Association of Southeast Asian Nations (ASEAN) between 1970-2008. The results indicated that economic globalization has a significantly positive influence on economic growth. The economic growth has influenced energy consumption like several authors have shown in their studies. Bozoklu and Yilanci (2013) examined the causal relationship between energy consumption and economic growth for 20 countries of Organisation for Economic Co-operation and Development (OECD). The empirical results pointed to causality direction between economic growth and energy consumption. Tang et al. (2013) studied the relationship between electricity consumption and economic growth in the Portuguese economy from 1971-2009. The authors found that the increase in real income has a positive impact on electricity consumption.

The model was based in the Unrestricted Error Correction Model (UECM) form of the auto-regressive distributive lag (ARDL). This article is organized as follows: in Section 2,-the literature review is presented. In Section 3, the model specification and databases used are presented. In Section 4, the empirical results and discussion. Finally, the conclusions are shown in Section 5.

\section{A BRIEF LITERATURE REVIEW}

\subsection{Globalization and Economic growth}

The relationship between globalization and growth has been conducted by a number of studies. Samimi and Jenatabadi (2014) examined the relationship between economic globalization and growth in a panel of selected OIC countries over the period 1980-2008. The results indicated a positive effect on growth in countries with better-educated workers and well-developed financial systems. Rao and Vadlamannati (2011) studied the globalization and growth nexus in low income African countries from 1970-2005.The results indicated that the positive effect of globalization on growth is larger than the effect of investment on growth. Dreher (2006) investigated the relationship between globalization and economic growth for a panel data of 123 countries in period from 1970-2000.The results showed that globalization promotes the growth. Rodriguez and Rodrik (2001) studied 95 countries in the period from 1976-1985. The estimation results pointed that globalization exerts a positive impact on growth.

\subsection{Economic growth and Energy consumption}

In the literature, several authors have contributed with studies addressing the relationship between growth and energy consumption. Shahbaz et al. (2013) examined the relationships between economic 
growth and energy consumption for the period from 1970-2009 in Portugal. The estimations pointed that economic growth has a positive impact on energy consumption. Solarin and Shahbaz (2013) found the existence of long run relationships between economic growth and energy consumption in Angola, utilizing the data from the period of 1971-2009. Dagher and Yacoubian (2012) investigated the dynamic causal relationship between energy consumption and economic growth in Lebanon from the period 1980-2009. The estimates showed a positive relationship between energy consumption and economic growth. Ozturk and Uddin (2012) identified a feedback relationship between energy consumption and growth in India from 1971-2007.

\section{MODEL SPECIFICATION AND DATA.}

\subsection{Model specification}

The model is based in the Unrestricted Error Correction Model (UECM) form of ARDL that decomposes the total effects in short- and long-run of the components of model. This model has the desired properties of generating consistent and efficient parameter estimates, and inference of parameters based on standard test.

The specification of the UECM form of the ARDL model comprises variables that are elasticity and semi-elasticity. In the model were used the prefixes (L) and (D) that denote natural logarithm and fist differences of variables. The following equation specifies the ARDL model:

$$
\begin{aligned}
L E_{i t}= & \alpha_{1 i}+\sum_{j=1}^{k} \beta_{11 i j} L G_{i t-j}+\sum_{j=0}^{k} \beta_{12 i j} L^{k} \text { OPEN }_{i t-j}+ \\
& \sum_{j=0}^{k} \beta_{13 i j} L Y_{i t-j}+\sum_{j=0}^{k} \beta_{14 i j} L C O 2_{i t-j}+\varepsilon_{1 i t}
\end{aligned}
$$

Where $\alpha_{1 i}$ denotes the intercept, and $\delta_{1 i}, \beta_{1 k i j}, k=1, \ldots .$. , are the estimated parameters, and $\varepsilon_{1 i}$ is the error term. To decompose the dynamic relationships of variables in short- and long-run the following equation was estimated:

$$
\begin{gathered}
D L E_{i t}=\alpha_{2 i}+\sum_{j=1}^{k} \beta_{21 i j} D L G_{i t-j}+\sum_{j-1}^{k} \beta_{22 i j} D L K O P E N_{i t-j}+\sum_{j=0}^{k} \beta_{23 i j} D L Y_{i t-j} \\
+\sum_{J=0}^{K} \beta_{24 i j} D L C O 2_{i t-j}+\gamma_{21 i} L E_{i t-1}+\gamma_{22 i} L G_{i t-1}+ \\
\gamma_{23 i} L K O P E N_{i t-1}+\gamma_{24 i} L Y_{i t-1}+\gamma_{25 i} L C O 2_{i t-1}+\varepsilon_{2 i t}
\end{gathered}
$$

Where $\alpha_{2 i}$ denotes the intercept, $\delta_{2 i}, \beta_{2 k i j}, k=1, \ldots, m$, and A $\gamma_{2 i m}$ is the estimated parameters, and $\varepsilon_{2 i} i$ is the error term. The Hausman test was used to identify the presence of Random Effects (RE) or Fixed Effects (FE) in the model. Table 1 reveals the coefficients of Hausman test. 
Table 1. Coefficients of Hausman test.

\begin{tabular}{|c|c|c|c|c|}
\hline \multicolumn{5}{|c|}{ Coefficients } \\
\hline Variables & Fixed (I) & $\begin{array}{c}\text { Random } \\
\text { (II) }\end{array}$ & $\begin{array}{c}\text { Difference } \\
\text { (I-II) }\end{array}$ & S. E \\
\hline LE & -0.5358 & -0.1262 & -0.4096 & 0.0543 \\
\hline LG & 0.2384 & 0.1571 & 0.0813 & 0.0392 \\
\hline LKOPEN & -0.0744 & -0.0651 & -0.0093 & 0.0185 \\
\hline LY & 0.1185 & -0.0029 & 0.1213 & 0.0579 \\
\hline LCO2 & 0.3097 & 0.0961 & 0.2136 & 0.0492 \\
\hline Test & \multicolumn{5}{|c|}{$\chi_{5}^{2}=63.07^{* * *}$} \\
\hline
\end{tabular}

Notes: Hausman test.HO: difference in coefficients not systematic. $* * *$ denote statistically significant at $1 \%$ level, respectively. The Stata command xtregwas used to achieve the results for Hausman test.

The null hypothesis of this test points that the best model is the Random effects (RE). The results points to selection of Fixed effect (FE) model, where the results are highly significant $\chi_{5}^{2}=63.07$. The selection of FE model evidences the correlation between countries individual effects, as well as the exploratory variables supporting that countries individual effects are statistically significant and included in the panel estimations. The FE model demonstrates suitability for analysing the influence of variables over time. The realization of heterogeneity parameters test in the macro panels is advisable, due to the presence of long-time spans and cross-sections. The heterogeneity parameters test could be of two types: (i) short-run and (ii) long-run. To deal with this, the Mean Group (MG) or Pooled Mena Group (PMG) estimators could be applied. These estimators require a large number of both cross-sections (N), and time of observations (T) (Blackburne III and Frank, 2007). The MG, according to Pesaran et al. (1999), is more flexible because it produces the regressions for each individual and computes an average coefficient of all individuals. The PMG estimations make restriction among cross-sections in long-run parameters, but nor in short-run, or in the adjustment speed term. Besides, the short-run dynamics are heterogeneous, while the long-run ones are homogeneous. Regarding the presence of long-run homogeneity, the PMG estimators is more efficient and consistent than the MG estimators. The dynamic FE estimator could be tested against MG or PMG estimators, to appraise the best estimator.

\subsection{Data}

The article examines twelve countries, namely: Argentina, Belize, Bolivia, Brazil, Chile, Colombia, Dominican Republic, Ecuador, Mexico, Nicaragua, Peru and Uruguay, from 1991-2012. The choice of LAC countries are justified, due to the fact that this region has passed by a process of globalization in the last two decades. Additionally, the choice of time series is acceptable due to the availability of existing data. To analyse the relationship between globalization and primary energy consumption, the following variables were used (see Table 2). 
Table 2. Variables in the model

\begin{tabular}{|l|l|l|l|}
\hline \multicolumn{2}{|l|}{ Variables } & Description & Source \\
\hline Primary Energy Consumption & LE & $\begin{array}{l}\text { Quadrillion Btu, from fossil fuel and } \\
\text { renewable sources. }\end{array}$ & $\begin{array}{l}\text { Energy Information } \\
\text { Administration (EIA). }\end{array}$ \\
\hline Index Globalization & LG & $\begin{array}{l}\text { Include economic, social and political } \\
\text { globalization. }\end{array}$ & KOF Index of Globalization. \\
\hline Capital Account Openness & LKOPEN & $\begin{array}{l}\text { index measuring a country's degree of } \\
\text { capital account openness. }\end{array}$ & The Chinn-Ito Index (KAOPEN). \\
\hline Gross Domestic Product (GDP) & LY & $\begin{array}{l}\text { GDP in constant local currency unity } \\
\text { (LCU). }\end{array}$ & The World Bank Data (WBD). \\
\hline $\begin{array}{l}\text { Carbon Dioxide Emissions } \\
\text { (CO2) }\end{array}$ & LCO2 & $\begin{array}{l}\text { From the consumption of energy in } \\
\text { million metric tons. }\end{array}$ & $\begin{array}{l}\text { Energy Information } \\
\text { Administration (EIA). }\end{array}$ \\
\hline Population & POP & Total of population. & The World Bank Data (WBD). \\
\hline Notes: This table was created by author. & & \\
\hline
\end{tabular}

The chosen variables have taken into account the following criteria (i) they have Primary energy consumption in a long period; and (ii) they have data available for the entire period. The variables in the analysis were transformed in per capita using the total of population, except the index globalization (LG) and capital account openness (LKOPEN). The option to use per capita values lets us control the disparities in population growth among the countries. Finally, the variables in the model were transformed in natural logarithms to minimize the fluctuations in the data series. The summary statistics are presented in Table 3.

Table 3. Descriptive statistics

\begin{tabular}{|l|l|l|l|l|l|}
\hline Descriptive statistics \\
\hline Variables & Obs & Mean & $\begin{array}{l}\text { Std. } \\
\text { Dev }\end{array}$ & Min. & Max. \\
\hline LE & 264 & -17.1853 & 0.5671 & -18.6029 & -16.2434 \\
\hline LG & 264 & 3.9805 & 0.1715 & 3.4717 & 4.3068 \\
\hline LKOPEN & 264 & 0.4134 & 0.2268 & 0.0000 & 0.6932 \\
\hline LY & 264 & 10.7098 & 2.5307 & 7.7480 & 16.1225 \\
\hline LCO2 & 264 & -13.2070 & 0.5233 & -14.6043 & -12.2706 \\
\hline DLE & 252 & 0.0219 & 0.0825 & -0.5104 & 0.3791 \\
\hline DLG & 252 & 0.0152 & 0.0378 & -0.0899 & 0.1898 \\
\hline DLKOPEN & 252 & 0.0109 & 0.0931 & -0.4267 & 0.4267 \\
\hline DLY & 252 & 0.0236 & 0.0333 & -0.1264 & 0.0999 \\
\hline DLCO2 & 252 & 0.0220 & 0.0968 & -0.8211 & 0.4456 \\
\hline Notes: The Stata command sum was used to descriptive statistics. \\
\hline
\end{tabular}

In the econometric analysis were used EViews 9.5 and Stata 14.0 software. The macro panel is common to test numerous possibilities that arise when data from a long period available. Indeed, the long-time spans have a potential of a panel with heterogeneity and phoneme of cross-section dependence. The appearance of cross-section dependence (CSD) is a common characteristic in the macro panel. The CSD was used to indicated the integration order of variables. Table 4 reveals, the results of the cross-section dependence of the variables. 
Table 4. Cross-section dependence test

\begin{tabular}{|c|c|c|c|c|}
\hline \multicolumn{5}{|c|}{ Cross-section dependence (CSD) } \\
\hline \multirow{2}{*}{$\begin{array}{l}\text { Variables } \\
\text { LE }\end{array}$} & \multicolumn{2}{|c|}{ CD test } & \multirow{2}{*}{\begin{tabular}{|l|} 
Corr. \\
0.729 \\
\end{tabular}} & \multirow{2}{*}{$\begin{array}{l}\text { Abs(Corr) } \\
0.729\end{array}$} \\
\hline & 27.77 & $* \star *$ & & \\
\hline LG & 30.28 & $* * *$ & 0.795 & 0.795 \\
\hline LKOPEN & 8.58 & $* * *$ & 0.225 & 0.488 \\
\hline LY & 34.07 & $* * *$ & 0.894 & 0.894 \\
\hline LCO2 & 20.31 & $* * *$ & 0.533 & 0.580 \\
\hline DLE & 7.55 & $* * *$ & 0.203 & 0.257 \\
\hline DLG & 5.05 & $* * *$ & 0.136 & 0.211 \\
\hline DLKOPEN & 0.76 & & 0.020 & 0.227 \\
\hline DLY & 8.70 & $* * *$ & 0.234 & 0.312 \\
\hline DLCO2 & 2.55 & * & 0.068 & 0.194 \\
\hline \multicolumn{5}{|c|}{$\begin{array}{l}\text { Notes: Pesaran (2004) CD test has } N(0,1) \text { distribution, under the } \mathrm{H}_{0} \text { : } \\
\text { cross-section independence. } * * *, * \text { denote statistically significant at } 1 \% \\
\text { and } 10 \% \text { level, respectively. The Stata command } x \text { tcd was used to achieve } \\
\text { the results for CSD. }\end{array}$} \\
\hline
\end{tabular}

The presence of cross-section dependence was identified in the variables on both the short- and long-run, expect the variables (DLKOPEN). A possible answer for results is that the variables in short-run capital account openness (DLKOPEN) does not impact on primary energy consumption (DLE). The results of cross-section dependence test points that the countries share common shocks, due to the existence of interdependence between the cross-sections.

The Variance Inflation Factor (VIF) was applied to check the presence of multicollinearity and the correlation of coefficients between variables. Table 5 reveals the results of matrices of correlation and VIF statistics.

Table 5.Matrices of correlations and VIF statistics

\begin{tabular}{|c|c|c|c|c|c|c|c|c|}
\hline Variables & \multicolumn{2}{|l|}{ LE } & \multicolumn{2}{|l|}{ LG } & \multirow[t]{2}{*}{ LKOPEN } & \multicolumn{2}{|l|}{ LY } & \multirow[t]{2}{*}{ LC02 } \\
\hline LE & 1.0000 & & & & & & & \\
\hline LG & 0.6324 & $\star \star * *$ & 1.0000 & & & & & \\
\hline LKOPEN & -0.1318 & & 0.4074 & $* * *$ & 1.0000 & & & \\
\hline LY & 0.2965 & $* * *$ & 0.3638 & $* * *$ & -0.1063 & 1.0000 & & \\
\hline LC02 & 0.9483 & $\star * *$ & 0.5361 & $* * *$ & -0.1435 & 0.2689 & $* * *$ & 1.0000 \\
\hline VIF & & & 2.48 & & 1.68 & 1.27 & & 1.81 \\
\hline Mean VIF & \multicolumn{8}{|l|}{1.81} \\
\hline Variables & DLE & & \multicolumn{2}{|l|}{ DLG } & \multirow[t]{2}{*}{ DLKOPEN } & \multicolumn{2}{|l|}{ DLY } & DLC02 \\
\hline DLE & 1.0000 & & & & & & & \\
\hline DLG & 0.0323 & & 1.0000 & & & & & \\
\hline DLKOPEN & 0.0170 & & 0.0139 & $* \star *$ & 1.0000 & & & \\
\hline DLY & 0.2250 & $* * *$ & 0.0397 & & 0.0750 & 1.0000 & & \\
\hline DLCO2 & 0.4903 & $* * *$ & 0.0771 & & 0.0530 & 0.2130 & $* * *$ & 1.0000 \\
\hline VIF & & & 1.01 & & 1.01 & 1.05 & & 1.05 \\
\hline Mean VIF & \multicolumn{8}{|l|}{1.03} \\
\hline
\end{tabular}

The correlation coefficients signal the absence of collinearity among variables. Despite this evidence, in order to solve any remaining doubt about collinearity, we also analyzed the Variance Inflation Factor (VIF) test for multicollinearity. The value of mean VIF is (1.81) to long-run and (1.03) to short-run. The low values for the individual VIF reveal that collinearity is not a problem in the model. The variable 
(LCO2) has high correlation with (LE). The possible reason for the high correlation between the variables may be that the $\mathrm{CO}_{2}$ emissions are composed of fossil fuels. To analyze the integration order of the variables, the second-generation unit root test (CIPS) (Pesaran, 2007) was applied. Table 6 shows the results of unit root test.

Table 6. Unit roots tests

\begin{tabular}{|l|l|l|l|l|}
\hline \multirow{2}{*}{ Variables } & \multicolumn{2}{|l|}{$\mathbf{2}^{\text {and }}$ Generation unit root test CIPS (Zt-bar) } & \multicolumn{2}{l|}{ With trend } \\
\cline { 2 - 5 } & Without trend & & 0.668 & $*$ \\
\hline LE & -0.322 & $*$ & -1.784 & \\
\hline LG & -1.983 & & 1.064 & \\
\hline LKOPEN & -0.845 & & -0.816 & \\
\hline LY & -0.221 & & 2.079 & $*$ \\
\hline LCO2 & 1.588 & $* * *$ & -1.705 & $* * *$ \\
\hline DLE & -3.783 & $* * *$ & -4.137 & $* * *$ \\
\hline DLG & -6.015 & $* * *$ & -4.863 & $* * *$ \\
\hline DLKOPEN & -4.566 & $* * *$ & -2.932 & $* * *$ \\
\hline DLY & -4.623 & -2.828 & \\
\hline DLCO2 & -3.923 & $* * *$ & \\
\hline $\begin{array}{l}\text { Notes: } * * * * \\
\text { Stata command multipurt was used to compute CIPS test. }\end{array}$ &
\end{tabular}

The second-generation unit root test (CIPS) was used without trend and with trend, and a lag length (1). The null hypothesis rejection of the CIPS test has $\mathrm{H}_{0}$ : series are I (1). The result of test (see Table 6) indicate that all variables short-run and long-run like (LG) are series of order I (1). The possible stationary in other variables in long-run are due several chocks that impacted the LAC region in the last three decades.

\section{EMPIRICAL RESULTS AND DISCUSSION}

The Westerlund cointegration test (2007) was used to check the cointegration between the variables. Table 7 reveals the results of Westerlund cointegration test.

Table 7. Results of Westerlund cointegration tests

\begin{tabular}{|c|c|c|c|c|}
\hline Statistics & \begin{tabular}{|l|} 
Value \\
\end{tabular} & Z-value & P-value & P-value robust \\
\hline Gt & -2.392 & 1.801 & 0.964 & 0.340 \\
\hline Ga & -4.035 & 5.341 & 1.000 & 0.578 \\
\hline $\mathbf{P t}$ & -3.642 & 5.464 & 1.000 & 0.848 \\
\hline $\mathrm{Pa}$ & -2.583 & 4.549 & 1.000 & 0.688 \\
\hline
\end{tabular}

To provide proper coefficients, standard errors, coefficient intervals and to disclose robust critical $p$-values it was used the bootstrapping option. The null hypothesis of Westerlund cointegration test $\mathrm{H}_{0}$ : No cointegration between variables. The results points to non-cointegration between variables. The non-cointegrated in the model is due to the fact that all variables in long-run are I (0). To test the heterogeneity parameters, the MG and PMG estimators were tested against the dynamic fixed effects (DFE). The heteroskedasticity contemporaneous, first order autocorrelation, the cross-section dependence in the context of a long time span, and the Driscoll and Kraay (1998) estimator was applied. The 
DFE estimator, DFE robust standard errors and DFE Driscoll an Kraay (DFE D.-K) were computed. The battery of specification test like the modified Wald test groupwise heteroscedasticity (Greence,2000), the Pesaran test of cross-section independence (Pesaran,2004), the Breusch-Pagan Langrarian Multiplier test (Greence,2000), and the Wooldridge test for autocorrelation in panel data (Wooldridge,2002) were used. Table 8 shows the results of the estimations.

Table 8. Estimations results

\begin{tabular}{|c|c|c|c|c|c|c|c|c|c|}
\hline \multicolumn{10}{|c|}{ Dependent Variable DLE } \\
\hline & \multicolumn{4}{|c|}{ Heterogeneous estimator } & \multicolumn{5}{|c|}{ Fixed effects } \\
\hline & MG (I) & & PMG (II) & & Coefficier & & FE (III) & $\begin{array}{l}\text { FE Robust } \\
\text { (IV) }\end{array}$ & $\begin{array}{l}\text { FE D.- } \\
\text { K. (V) }\end{array}$ \\
\hline Constant & -13.1457 & $* * *$ & -3.8558 & $* * *$ & -7.2984 & $* * *$ & $* * *$ & $* * *$ & $\star * *$ \\
\hline & \multicolumn{9}{|c|}{ Short-run (semi-elasticities) } \\
\hline DLG & -0.0952 & & -0.1857 & & 0.0077 & & & & \\
\hline DLKOPEN & -0.0441 & & 0.0234 & & -0.0604 & & & & \\
\hline DLY & 0.2393 & & 0.3038 & $* * *$ & 0.2336 & * & * & * & * \\
\hline \multirow[t]{2}{*}{ DLCO2 } & 0.4564 & *** & 0.5017 & $* * *$ & 0.4954 & $* * *$ & $* * *$ & $* * *$ & $* * *$ \\
\hline & \multicolumn{9}{|c|}{ Long-run (elasticities) } \\
\hline LG (-1) & 0.1977 & & 0.1704 & $* * *$ & 0.4449 & $* * *$ & $* * *$ & $* * *$ & $* * *$ \\
\hline LKOPEN (-1) & -0.0422 & & 0.0304 & & -0.1389 & ** & ** & ** & ** \\
\hline $\operatorname{LY}(-1)$ & 0.4941 & $* * *$ & 0.0721 & & 0.2211 & ** & ** & ** & ** \\
\hline \multirow[t]{2}{*}{$\operatorname{LC02}(-1)$} & 0.3704 & * & 0.8408 & $* * *$ & 0.5780 & $* * *$ & $* * *$ & $* * *$ & $* * *$ \\
\hline & \multicolumn{9}{|c|}{ Speed of adjustment } \\
\hline \multirow[t]{4}{*}{ ECM } & -0.9318 & $* * *$ & -0.5133 & $* * *$ & -0.5358 & $\star * *$ & $* * *$ & $* * *$ & $* * *$ \\
\hline & \multicolumn{4}{|c|}{ Hausman test } & \multicolumn{5}{|c|}{ Specification test } \\
\hline & \multicolumn{2}{|c|}{ MG vs PMG } & \multicolumn{2}{|c|}{ PMG vs DFE } & \multicolumn{2}{|c|}{ Modified Wald test } & Pesaran test & \multicolumn{2}{|c|}{ Wooldridge test } \\
\hline & \multicolumn{2}{|c|}{$\chi_{10}^{2}={ }_{-9.55}$} & \multicolumn{2}{|c|}{$\chi_{10}^{2}=0.98^{* * *}$} & \multicolumn{2}{|c|}{$\chi_{12}^{2}={ }_{11079.97^{* * *}}$} & $4.619 * * *$ & \multicolumn{2}{|c|}{$\begin{array}{l}F(1,11) \\
=247.683^{* * *}\end{array}$} \\
\hline \multicolumn{10}{|c|}{$\begin{array}{l}\text { Notes: } * * *, * *, * \text { denote statistically significantat } 1 \%, 5 \% \text { and } 10 \% \text { level, respectively; Hausman results for } \mathrm{H}_{0} \text { : Difference } \\
\text { in coefficients not systematic; ECM denotes error correction mechanism; the long-run parameters are computed } \\
\text { elasticities; the Stata commands } x \text { tpmg, and Hausman (with the sigmamore option) were used; In the fixed effects } \\
\text { were used the } x \text { treg, and } x t s c c \text { Stata commands; For } \mathrm{H}_{0} \text { of Modified Wald test: sigma(i)^ } 2=\text { sigma } 2 \text { for all I; results } \\
\text { for } \mathrm{H}_{0} \text { of Pesaran test: residuals are not correlated; results for } \mathrm{H}_{0} \text { of Wooldridge test: no first-order autocorrelation. }\end{array}$} \\
\hline
\end{tabular}

The heterogeneity parameters and Hausman test evidence that the DFE is an appropriate estimator, even as evidence that panel is homogeneous. The estimations result of DFE estimator, DFE robust standard errors, and DFE Driscoll and Kraay (DFE D.-K.) points to the presence of long memory of the variables characterized by statically significant ECM term. The ECM term is statically significant at $1 \%$ level and has a negative signal, confirming the presence of Granger causality. The battery of specification tests, like the modified Wald test, points to the presence of heteroscedasticity, due to statistically highly significant $\chi_{12}^{2}=11079.97$. The Pesaran test of cross-section independence confirms the presence of cross-section independence in the model, due to the highly significant (4.619***). The Breusch-Pagan LM test cannot be carried, because the correlation matrix of residuals is singular. The Wooldridge test is statistically highly significant $F(1,11)=247.683$, evidencing the presence of first order autocorrelation. The elasticity results shows that increase of $1 \%$ on variable (LG) exerts a positive impact of $(0.4449 \%)$ on (LE) in the long-run. Furthermore, the variables (LY) and (LCO2) exert a positive impact in the short and long-run (see Table 5). Nonetheless, the variable (LKOPEN) has a negative impact of $(-0.1389 \%)$ in the long-run. 
The positive relationship between globalization and primary energy consumption is due the improvement of the total factor productivity, and economic growth that influences the energy demand as pointed by Shahbaz et al. (2015). This study confirms that economic growth increases energy consumption (see for example, Leitão,2014; Shahbaz et al. 2013; Dagher and Yacoubian, 2012; Ozturk and Uddin, 2012) where, the economic activity determines the increase of energy demand. The results also reveal that dioxide carbon emissions increase energy consumption. These results were confirmed by Saidi and Hammami, 2015; Shahbaz et al. 2014; Sheinbaum-Pardo et al. 2012; Arouri et al. 2012; Niu et al. 2011. The possible reason for the positive relationship between dioxide carbon emissions and energy consumption may be that in developing countries the energy efficiency is much lower than in developed ones (Niu et al. 2011). An interesting point in the results is that the capital account openness has a negative impact, the possible cause to this effect being that the low capital account openness in LAC prevents a higher influence on energy consumption.

\section{CONCLUSIONS}

This article investigated the relationship between globalization and primary energy consumption in twelve LAC countries from 1991 to 2012 using ARDL methodology. The presence of cross-section dependence was detected, as well as the estimation results pointed to the presence of Granger causality. The elasticities results showed that the increase of $1 \%$ on variable (LG) exerts a positive impact of $(0.4449 \%)$ in the long run on the variable (LE). The positive relationship between globalization and primary energy consumption is due the globalization promotes the economic growth that influences energy demand. The variables (LY) and (LCO2) exert a positive impact in short and long run, as well as the variable (LKOPEN) has a negative impact of $(-0.1389 \%)$ in long run. The heterogeneity parameters and Hausman test pointed that the DFE is an appropriate estimator, as well as evidence that panel is homogeneous. The battery of specification tests, like the modified Wald test, pointed to presence of heteroscedasticity. The Pesaran test of cross-section independence confirmed the presence of cross-section independence in the model.

\section{ACKNOWLEDGMENTS}

The financial support of the NECE - Research Unit in Business Science and Economics, sponsored by the FCT - Portuguese Foundation for the Development of Science and Technology, Ministry of Education and Science, project UID/GES/04630/2013, is acknowledged. 


\section{REFERENCES}

Arouri, M.E.H.; Youssef, A.B.; M'henni, H.; Rault, C. Energy consumption, economic growth and $\mathrm{CO}_{2}$ emissions in Middle East and North African countries. Energy Policy, v.45, pp.342-349, 2012.doi.10.1016/j. enpol.2012.02.042.

Bozoklu, S.; Yilanci, V.Energy consumption and economic growth for selected OECD countries: Further evidence from Granger causality test in the frequency domain. Energy Policy,v. 63, pp. 877-881, 2013. doi.10.1016/j.enpol.2013.09.037.

Blackburne III, E.F.; Frank, M.W. Estimation of non-stationary heterogeneous panels. The Stata Journal, v.7, n. 2, pp.197-208,2007.URL: http://www.stata-journal.com/article.html?article=st0125.

Dreher, A. Does globalization affects growth? Empirical evidence from a New Index. Applied Economics, v.38, n. 10, pp.1091-1110,2006. doi.10.1080/00036840500392078.

Dagher, L.; Yacoubian, T.The causal relationship between energy consumption and economic growth in Lebanon.Energy Policy, v.50, pp.795-801,2012. doi.10.1016/j.enpol.2012.08.034.

Driscoll, J.; Kraay, A.C. Consistent covariance matrix estimation with spatially dependent data. Review of Economics and Statistics, v. 80, n. 4, pp.549-560,1998.doi: 10.1162/003465398557825.

Greene, W. Econometric analysis. Upper Saddle River, New Jersey: Prentice-Hall,2000.

Gurgul, H.; Lach, L. Globalization and economic growth: Evidence from two decades of transition in CEE. Economic Modelling,v.36, pp. 99-107,2014. doi.10.1016/j.econmod.2013.09.022.

Leitão, N.C. Economic growth, carbon dioxide emissions, renewable energy and globalization.International Journal of Energy Economics and Policy,v. 4, n. 3, pp.391-399,2014. URL: http://www.econjournals.com/ index.php/ijeep/article/view/830/465.

Niu, S.; Ding, Y.; Niu, Y.; Li, Y.; Luo, G. Economic growth, energy conservation and emissions reduction: a comparative analysis based on panel data for 8 Asian-Pacific countries. Energy Policy, v.39, n. 4, pp. 2121-2131,2011. doi.10.1016/j.enpol.2011.02.003.

Ozturk, I.; Uddin, G.S. Causality among carbon emissions, energy consumption andgrowth in India. Economic Research, v. 25, n.3, pp.752-775,2012. URL: http://hrcak.srce.hr/file/142717.

Pesaran, M. H. General diagnostic tests for cross section dependence in panels. University of Cambridge, Faculty of Economics. Cambridge Working Papers in Economics n. 0435,2004.URL: http://www.econ. cam.ac.uk/research/repec/cam/pdf/cwpe0435.pdf.

Pesaran, M.H.; Shin, Y.; Smith, R.P. Pooled mean group estimation of dynamic heterogeneous panels. Journal of American Statistical Association, v. 94, n.446, pp.621-634,1999.URL: http://www.jstor.org/ stable/2670182.

Pesaran, M.H. A simple panel unit root test in the presence of cross-section dependence. Journal of Applied Econometrics, v. 22, n.2, pp.256-312,2007. doi.: 10.1002/jae.951. 
Rao, B.B.; Vadlamannati, K.C. Globalization and growth in the low income African countries with the extreme bounds analysis. Economic Modelling, v.28, n.3, pp.795-805,2011.10.1016/j.econmod.2010.10.009.

Rodriguez, F.; Rodrik, D. Trade policy and economic growth: a skeptic's guide to the cross-national evidence. NBER Macroeconomics Annual, v.15, pp.261-325,2001. URL:http://www.nber.org/books/ bern01-1.

Samimi, P.;Jenatabadi, S.H. Globalization and economic growth: Empirical evidence on the role of complementarities. Plos One, v. 9, n.4, pp.1-7, 2014. doi.: 10.1371/journal.pone.0087824.

Saidi, K.;Hammami, S. The impact of $\mathrm{CO}_{2}$ emissions and economic growth on energy consumption in 58 countries.Energy Reports, v. 1, pp. 62-70,2015. doi.10.1016/j.egyr.2015.01.003.

Shahbaz, M.; Khan, S.; Ali, A.; Bhattacharya, M. The Impact of globalization on $\mathrm{CO}_{2}$ emissions in China. Munich Personal RePEc Archive, n. 64450,2015. URL: https://mpra.ub.uni-muenchen.de/64450/.

Shahbaz, M.; Leitão, N.C. Portuguese carbon dioxide emissions and economic growth: A time series analysis. Bulletin of Energy Economics, v.1 n. 1, pp.1-7, 2013. URL: http://tesdo.org/journal_detail. php?paper_id=20\&expand_year=2013.

Shahbaz, M; Nazreen, S.; Afza, T. Environmental consequences of economic growth and foreign direct investment: evidence from panel data analysis.Bulletin of Energy Economics, v.2 n. 2, pp.14-27. URL: http://EconPapers.repec.org/RePEc:ijr:beejor:v:2:y:2014:i:2:p:14-27.

Sheinbaum-Pardo, C.; Mora-Perez, S.; Robles-Morales, G. Decomposition of energy consumption and $\mathrm{CO}_{2}$ emissions in Mexican manufacturing industries: Trends between 1990 and 2008 Energy Sustain. Energy for Sustainable Development, v.16, n.1, pp.57-67. doi.10.1016/j.esd.2011.08.003.

Solarin, S.A.; Shahbaz, M. Trivariate causality between economic growth in Angola: Cointegration and causality analysis.Energy Policy, v. 60, pp.876-884,2013. doi.10.1016/j.enpol.2013.05.058.

Tang, C.F.; Shahbaz, M.; Aurori, M. Re-investigating the electricity consumption and economic Growth nexus in Portugal.Energy Policy, v.62, pp.1515-1524,2013. doi.10.1016/j.enpol.2013.07.073.

Ying, Y-H.; Chang, K.; Lee, C-H. The impact of globalization on economic growth.Romanian Journal of Economic Forecasting, v.17, n.2, pp25-34,2014. URL: http://www.ipe.ro/rjef/rjef2_14/rjef2_2014p25-34.pdf.

Wooldridge, J. M. Econometric analysis of cross section and panel data. Cambridge, Massachusetts: The MIT Press, 2002.

Westerlund, J. Testing for error correction in panel data. Oxford Economics and Statistics, v. 31, n.2, p.217-224, 2007.doi. 10.1111/j.1468-0084.2007.00477. x. 